\title{
Optimization of biodiesel production from oils and fats with high free fatty acids Math M. C ${ }^{1}$, Sudheer Prem Kumar ${ }^{2}$ and Soma V. Chetty ${ }^{3}$ ${ }^{1}$ Dept. of Mechanical Engineering, Jawaharlal Nehru Technological University, Hyderabad-500085, India. Dept. of Mechanical Engineering, Sir M. Visvesvaraya Institute of Technology, Bangalore -562157 \\ ${ }^{2}$ Dept of Mechanical Engineering, Jawaharlal Nehru Technological University, Hyderabad-500085, India. ${ }^{3}$ Kuppam College of Engineering, Kuppam -517425 (AP).
} mcmath1018@yahoo.com

\begin{abstract}
Biodiesel may be cost effective if produced from low cost feedstock such as animal fats, restaurant waste oil and frying oil, which contains high amount of free fatty acids (FFA). In the present work, two-stage transesterification process was used to convert a mixture of $75 \%$ restaurant waste oil and $25 \%$ pig fat oil (PFO) into restaurant waste oil pig fat methyl ester (RWOPFME). Different amounts of methanol $(25,30,35,40,45$ and $50 \%$ by vol.), alkaline catalyst $(\mathrm{NaOH})$ concentrations $\left(0.3,0.5,0.7\right.$, and $0.9 \%$ by wt.), reaction temperature $\left(55^{\circ} \mathrm{C}, 60^{\circ} \mathrm{C}\right.$ and $\left.65^{\circ} \mathrm{C}\right)$ and reaction time $(90,120$ and $150 \mathrm{~min}$ ) were selected for the transesterification process in order to optimize the experimental conditions for maximum biodiesel yield. Amount of $\mathrm{H}_{2} \mathrm{SO}_{4}(1.5 \mathrm{ml})$ was kept constant. Maximum yield $(80 \%$ by vol.) at optimized process parameters such as methanol $(40 \%), \mathrm{NaOH}(0.3 \mathrm{~g})$, reaction temperature $\left(65^{\circ} \mathrm{C}\right)$, reaction time $(90 \mathrm{~min})$ and $\mathrm{H}_{2} \mathrm{SO}_{4}(1.5 \mathrm{ml})$ was obtained.
\end{abstract}

Keywords: Biodiesel, free fatty acids, restaurant waste oil pig fat methyl ester (RWOPFME), transesterification.

\section{Introduction}

Biodiesel is gaining attention worldwide as an alternative automotive fuel due to depletion of petroleum products at faster rate and strict environment regulations. Biodiesel is an oxygenated, sulfur free, biodegradable, non-toxic, and environmentally friendly alternative automotive fuel. It can be produced from renewable sources such as vegetable oils, animal fats, restaurant waste oil and frying oil. Its use does not require any major modifications in the existing diesel engine. The major constraint in wide spread use of biodiesel is the production cost. Considerable research work has been done to reduce the cost of biodiesel by using low cost feed stocks such as animal fats, restaurant waste oil and frying oil (Laguë et al., 1988; Mittelbach et al., 1992; Cankci \& VanGerpen, 1999; Cankci \& VanGerpen, 2001). These low cost feedstocks are more challenging to process because they contain high amount of free fatty acids (FFA). This paper presents the use of two stage transesterification process for the conversion of a mixture of $75 \%$ restaurant waste oil and $25 \%$ pig fat into restaurant waste oil pig fat methyl ester (RWOPFME) and optimization of process parameters for maximum biodiesel yield.

\section{Materials and methods}

Two stage transesterification process used for the production of biodiesel is as shown in the Fig. 1 . In the first stage, concentrated $\mathrm{H}_{2} \mathrm{SO}_{4}(95 \%$ purity) was used as an acidic catalyst to convert high FFAs to esters and in the second stage $\mathrm{NaOH}$ is used as an alkaline catalyst to convert triglycerides to Biodiesel (Cankci \& VanGerpen, 2001). Transesterification process is affected by parameters like amount of methanol, concentration of $\mathrm{NaOH}$, amount of $\mathrm{H}_{2} \mathrm{SO}_{4}$, reaction temperature and reaction time (Freedman et al., 1984; Ma et al., 1998; Leung \& Guo, 2006; Math \& Irfan, 2007). One of the most important variables affecting the yield of biodiesel is the molar ratio of alcohol to vegetable oil used (Freedman et al., 1984). The stoichiometry of this reaction requires 3 $\mathrm{mol}$ of alcohol per mol of triglyceride to yield $3 \mathrm{~mol}$ of fatty ester and $1 \mathrm{~mol}$ of glycerol. Several researchers proposed a molar ratio of 5:1 for maximum biodiesel yield, hence, in order to optimize the amount of methanol, six samples were prepared by varying the amount of methanol $(25,30,35,40,45$ and $50 \%$ by vol) by keeping $\mathrm{NaOH}$ concentrations, $\mathrm{H}_{2} \mathrm{SO}_{4}$ amount, reaction temperature and reaction time were kept constant throughout the process.

In several research work (Leung \& Guo, 2006), $\mathrm{NaOH}$ (0.1-1\% by weight) has been used for biodiesel production. In the present work, to optimize the amount of $\mathrm{NaOH}$, four samples were prepared by varying the amount of $\mathrm{NaOH}(0.3,0.5,0.7$, and $0.9 \%$ by wt) by keeping all other parameters constant. Sodium methoxide solution was prepared by dissolving $\mathrm{NaOH}$ pellets in methanol.

Reaction temperature influences the rate of reaction and biodiesel yield. Several researchers proposed that transesterification process may be carried out at a temperature nearer to boiling point of alcohol (Ma et al., 1998) hence in order to optimize the reaction temperature, three samples were prepared by varying the reaction temperature $\left(55^{\circ} \mathrm{C}, 60^{\circ} \mathrm{C}\right.$ and $\left.65^{\circ} \mathrm{C}\right)$ by keeping all other parameters constant.

Several investigators have studied the effect of reaction time on biodiesel yield (Freedman et al., 1984). In this work experiments were carried at three reaction time $(90,120$ and $150 \mathrm{~min})$ by keeping all other parameters constant in order to optimize the reaction time.

Research article

OIndian Society for Education and Environment (iSee)

"Biofuel from restaurant waste oil" http://www.indjst.org
Math et al. Indian J.Sci.Technol. 
Fig. 1. Process diagram

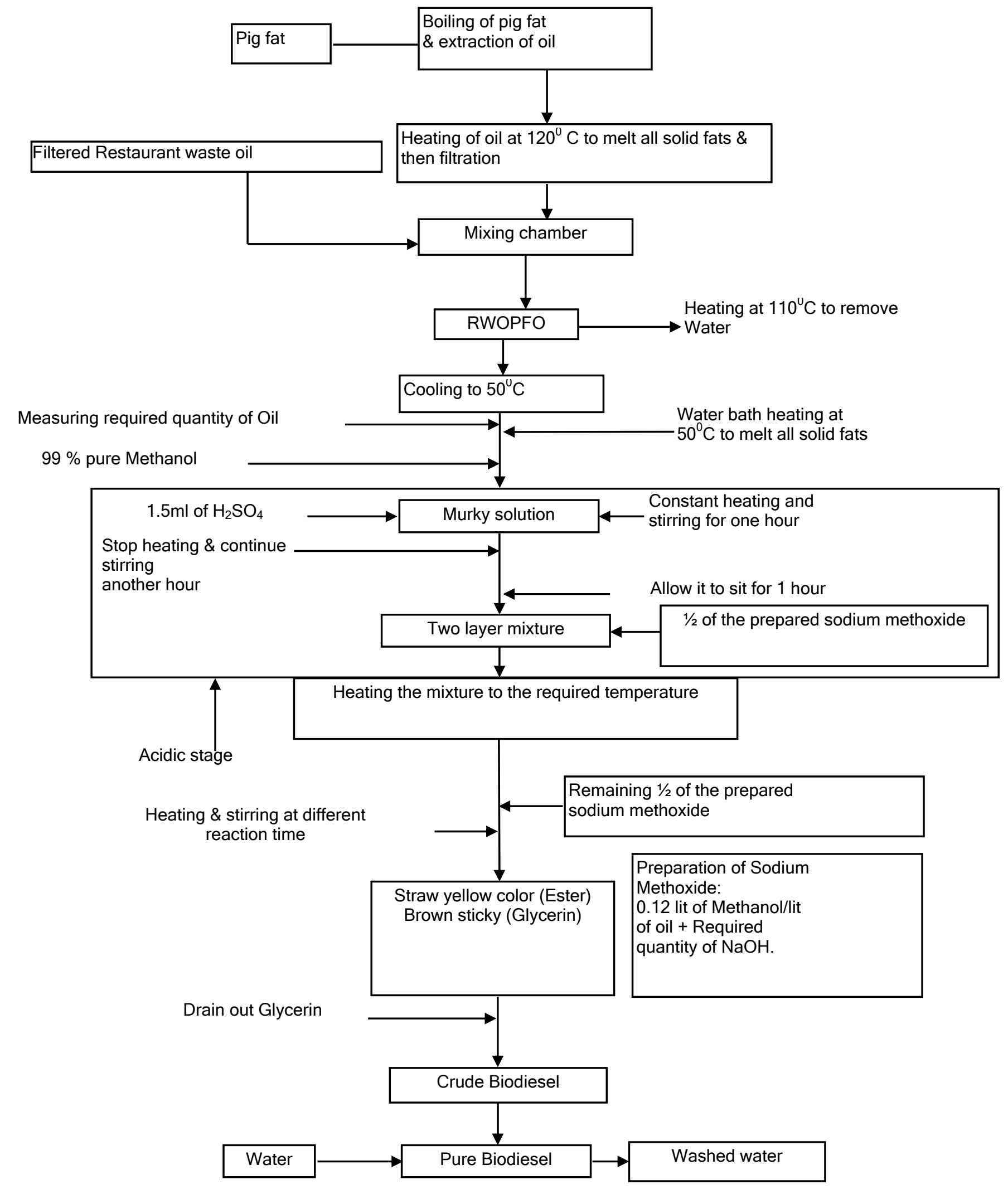



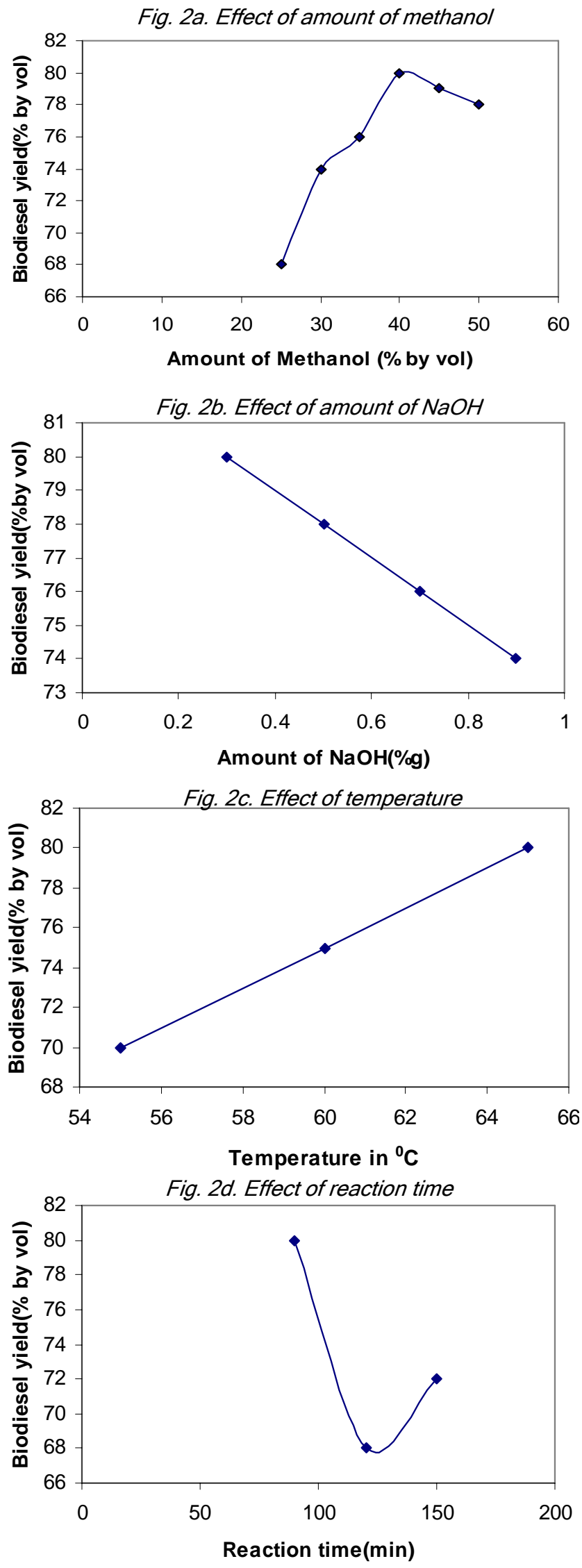

Vol. 3 No. 3 (Mar 2010)

ISSN: 0974- 6846

\section{Experimental method}

Clean mixture of $75 \%$ restaurant waste oil and $25 \%$ pig fat oil $(100 \mathrm{ml})$ was taken in each of six conical flasks and then heated to $120^{\circ} \mathrm{C}$ for $15 \mathrm{~min}$ in order to melt all solid fats. This mixture is allowed to cool to a temperature of $50^{\circ} \mathrm{C}$ and then required amount of methanol (99\% purity) is added to the heated mixture of each flask. After stirring for $15 \mathrm{~min}$, the solution became murky. To this solution, $1.5 \mathrm{ml}$ of $\mathrm{H}_{2} \mathrm{SO}_{4}$ is added. Stirring continued for $1 \mathrm{~h}$ by maintaining temperature at $50^{\circ} \mathrm{C}$. After this, heating was stopped and stirring is continued for another $1 \mathrm{~h}$. In the mean time, sodium methoxide solution was prepared by dissolving different amount of alkaline catalyst in 0.12 I of methanol per liter of oil. Half of the prepared sodium methoxide solution is added to this mixture and then heated to the required reaction temperature. To this mixture, remaining half of the sodium methoxide solution is added. Heating and stirring continued at different reaction time. Mixture was allowed to separate and settle overnight by gravity settling into clear, golden color liquid biodiesel at the top and light brown glycerol at the bottom. Next day, glycerol was drained off, leaving biodiesel and it was water washed two times.

\section{Results and discussion \\ Effect of molar ratios}

The influences of methanol/oil molar ratio on biodiesel yield are shown in Table 1 and represented in Fig. 2a. At $40 \%$ (by vol) methanol, maximum biodiesel yield (80\%) was obtained. The result indicated that excess use of methanol had no significant effect on biodiesel yield and in fact complicate ester and glycerol separation.

Effect of Catalyst

Fig. $2 \mathrm{~b}$ shows the effect on amount of $\mathrm{NaOH}$ on biodiesel yield. The optimum catalyst amount was found to be $0.3 \%$ and yield reached $80 \%$. The extra amount of catalyst did not contribute to an increase in biodiesel yield. This was probably because the slurry became too viscous, making it to difficult for stirring and consumes more energy.

\section{Effect of reaction temperature}

Fig. 2c shows the effect on reaction temperature on biodiesel yield. The optimum temperature was found to be $65^{\circ} \mathrm{C}$ and yield was $80 \%$.

Effect of reaction time

Fig. $2 \mathrm{~d}$ shows the effect on reaction time on biodiesel yield. In this study, three reaction times were selected $(90,120$ and $150 \mathrm{~min})$. Maximum biodiesel $(80 \%)$ was obtained at $90 \mathrm{~min}$ reaction time. Rate of reaction increased with increase in reaction time and reached maximum at 90 min, then it remained almost constant.

\section{Conclusions}

Optimum values of methanol $(40 \%)$, alkaline catalyst $\mathrm{NaOH}(0.3 \%)$, reaction temperature $\left(65^{\circ} \mathrm{C}\right)$ and reaction time $(90 \mathrm{~min})$ for the transesterification of mixture of $75 \%$ restaurant waste oil and $25 \%$ pig fat into restaurant waste
Research article

CIndian Society for Education and Environment (iSee)
"Biofuel from restaurant waste oil" http://www.indjst.org
Math et al. Indian J.Sci.Technol. 
Table 1. Optimized process parameters for maximum biodiesel yield

\begin{tabular}{|c|c|c|c|c|c|c|c|}
\hline Samples & $\begin{array}{l}\text { RWOPF } \\
(\mathrm{ml})\end{array}$ & $\begin{array}{l}\text { Methanol } \\
(\mathrm{ml})\end{array}$ & $\begin{array}{c}\text { Acidic catalyst } \\
\left(\mathrm{H}_{2} \mathrm{SO}_{4}\right) \mathrm{ml}\end{array}$ & $\begin{array}{l}\text { Basic catalyst } \\
(\mathrm{NaOH}) \mathrm{g}\end{array}$ & $\begin{array}{l}\text { Reaction } \\
\text { temp. }\left({ }^{0} \mathrm{C}\right)\end{array}$ & $\begin{array}{c}\text { Reaction } \\
\text { Time (min) }\end{array}$ & $\begin{array}{c}\text { RWOFPME } \\
\text { (biodiesel) } \mathrm{ml}\end{array}$ \\
\hline $\mathrm{S} 1$ & \multirow{13}{*}{100} & 25 & \multirow[t]{13}{*}{$1,1<<-4,1 \cdots$} & \multirow{6}{*}{0.3} & \multirow{9}{*}{ (0) } & \multirow[t]{11}{*}{ (n) } & 68 \\
\hline $\mathrm{S} 2$ & & 30 & & & & & 74 \\
\hline S3 & & 35 & & & & & 76 \\
\hline S4 & & 40 & & & & & 80 \\
\hline S5 & & 45 & & & & & 79 \\
\hline S6 & & 50 & & & & & 78 \\
\hline S7 & & \multirow{7}{*}{40} & & 0.5 & & & 78 \\
\hline S8 & & & & 0.7 & & & 76 \\
\hline S9 & & & & 0.9 & & & 74 \\
\hline $\mathrm{S} 10$ & & & & \multirow{4}{*}{0.5} & 60 & & 75 \\
\hline $\mathrm{S} 11$ & & & & & 55 & & 70 \\
\hline $\mathrm{S} 12$ & & & & & \multirow{2}{*}{60} & 120 & 68 \\
\hline $\mathrm{S} 13$ & & & & & & 150 & 72 \\
\hline
\end{tabular}

Conf. St. Josep.Mich., ASAE. 74-78.

Table 2. Comparison of parameters for the maximum biodiesel yield for different feedstock $(100 \mathrm{ml})$

\begin{tabular}{|c|c|c|c|c|c|c|c|}
\hline Type of feedstock & $\begin{array}{c}\text { Method of } \\
\text { biodiesel } \\
\text { production }\end{array}$ & $\begin{array}{c}\text { Methanol } \\
(\mathrm{ml})\end{array}$ & $\begin{array}{c}\text { Acidic } \\
\text { catalyst } \\
\left(\mathrm{H}_{2} \mathrm{SO}_{4}\right) \mathrm{ml}\end{array}$ & $\begin{array}{c}\text { Basic } \\
\text { catalyst } \\
(\mathrm{NaOH}) \mathrm{g}\end{array}$ & $\begin{array}{c}\text { Reaction } \\
\text { temp. } \\
\left({ }^{0} \mathrm{C}\right)\end{array}$ & $\begin{array}{c}\text { Reaction } \\
\text { time } \\
(\mathrm{min})\end{array}$ & $\begin{array}{c}\text { Maximum } \\
\text { biodiesel } \\
\text { yield ml }\end{array}$ \\
\hline $\begin{array}{c}\text { Restaurant waste oil } \\
\text { (Math \& Iffan, 2007) }\end{array}$ & $\begin{array}{c}\text { 2-stage } \\
\text { transesterifica }\end{array}$ & 35 & 1.0 & 0.3 & 55 & 90 & 85.50 \\
\cline { 1 - 6 } $\begin{array}{c}75 \% \text { restaurant waste oil } \\
+25 \% \text { pig fat }\end{array}$ & tion & 40 & 1.5 & 0.3 & 65 & 90 & 80.00 \\
\hline
\end{tabular}

oil pig fat methyl esters was obtained by varying methanol amount $(25-50 \%$ by vol), $\mathrm{NaOH}$ concentration $(0.3-0.7 \%$ by $\mathrm{wt})$, reaction temperature $\left(55-65^{\circ} \mathrm{C}\right)$ and reaction time (90-120 min). Maximum yield of $80 \%$ biodiesel was obtained at the optimum amount of methanol (Fig. 2a), concentration of $\mathrm{NaOH}$ (Fig. 2b), reaction temperature (Fig. 2c) and reaction time (Fig. 2d).

\section{References}

1. Cankci M and VanGerpen J (2001) Biodiesel production from oils and fats with high free fatty acids, Transaction of ASAE. 44(6), 1429-1436.

2. Cankci M and Van Gerpen (1999) Biodiesel production via acid catalyst. Trans. ASAE. 42(5), 1203-1210.

3. Cigizoglu KB, Ozaktas T and Karaosmanoglu F (1997) Used sunflower oil as an alternative fuel for diesel engines. Energy Sources.19, 559-556.

4. Freedman B, Pyrde EH and Mounts TL (1984) Variables affecting the yields of fatty esters from transesterified vegetable oils. JAOCS. 61,1638-1643.

5. Jeromin L, Peukert E and Wollmann G (1987) Process for the pre-esterification of free fatty acids in fats and oils. US Patent, 4698186.

6. Laguë CM, Lo KV and Staley LM (1988) Waste vegetable oil as a diesel fuel extender. Can. Agri. Engg. 30(1), 27-32.

7. Leung DY and Guo Y (2006) Transesterification of neat \& used frying oil: optimization for biodiesel production. Fuel proc. technol. 87, 883-890.
8. Ma F, Clements LD and Hanna MA (1998) The effects of catalyst, fatty acids and water on transesterification of beef tallow. Trans. ASAE. 41, 1261-1264.

9. Math MC and Irfan G (2007) Optimization of restaurant waste oil methyl ester yield. J. Sci. Ind. Res. 66,,772-776.

10. Mittelbach M, Porkits B and Silberholz (1992) Production and fuel properties of fatty acid methyl esters from used frying oil. Proc. Alternative Energy
"Biofuel from restaurant waste oil" http://www.indjst.org
Math et al. Indian J.Sci.Technol. 